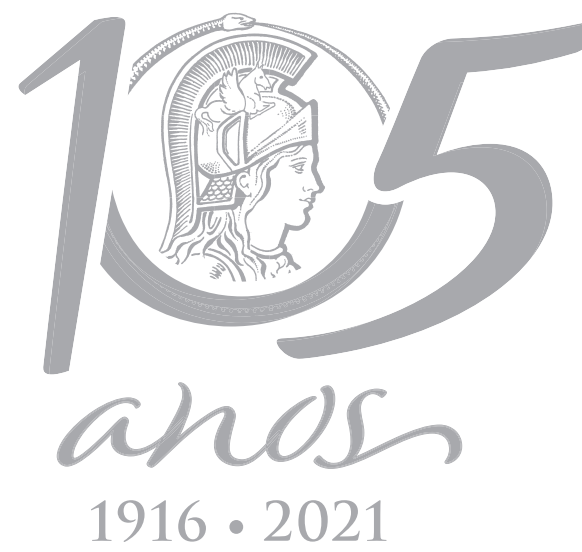

\title{
ECOSYSTEMS
}

\section{A New Species of Hershkovitzia (Diptera: Nycteribiidae) from Maranhão, Brazil}

\author{
GABRIELA HRYCYNA, CIRO L.C. DOS SANTOS, JOSÉ M.M. REBÊLO \& GUSTAVO \\ GRACIOLLI
}

\begin{abstract}
Hershkovitzia Guimarães \& D'Andretta, 1956 belongs to Nycteribiidae, composed of hematophagous species exclusively ectoparasites of bats. The new species was collected from the bat Thyroptera devivoi Gregorin, Gonçalves, Lim \& Engstrom, 2006 (Chiroptera: Thyropteridae) from Barreirinhas in Maranhão State, Brazil. Herein, we proposed schematic drawings of the abdomen, legs and head. We also proposed an identification key to species of Hershkovitzia.
\end{abstract}

Key words: bat fly, taxonomy, Thyroptera, Chiroptera.

\section{INTRODUCTION}

Nycteribiidae (Diptera: Hippoboscoidea) is composed of hematophagous flies that are exclusive ectoparasites of bats (Peterson \& Wenzel 1987, Graciolli 2010). The family is divided into three subfamilies, including Nycteribiinae, Cyclopodiinae and Archinycteribiinae, with a total of 11 genera and 276 species (Graciolli 2010, Graciolli et al. 2016, Graciolli \& Dick 2018). Most genera and species are found in the Old World with nine genera and 223 species, including 66 species reported to Basilia. In the New World, only two genera of the subfamily Nycteribiinae are known. Basilia Miranda-Ribeiro, 1903, currently contains 116 described species, of which 49 are restricted to the New World. On the other hand, Hershkovitzia Guimarães \& D'Andretta, 1956, contains four described species (H. cabala Peterson \& Lacey, 1985; H. coeca Theodor, 1967; H. inaequalis Theodor, 1967 and H. primitiva Guimarães \& D'Andretta, 1956), all restricted to the Neotropical Region (Graciolli et al. 2007, 2016, Graciolli \& Dick 2018).
Hershkovitzia is morphologically characterized as follows: head laterally compressed, pigmented eyes formed by a single facet, thin pedipalps, and presence of thoracic ctenidium. The abdomen of females has seven dorsal sclerotined plates (syntergites $1+2$ and five tergites), seven ventral ones (sternite 1+2 and five sternites), and one genital plate. Males present six dorsal plates (syntergite $1+2$ and four tergites), five ventrals (sternite $1+2$ and three sternites), a genital plate and phallobase divided longitudinally in two (Guimarães \& D'Andretta 1956). Guimarães \& D'Andretta proposed Hershkovitzia in 1956 in a synopsis of American species of Nycteribiidae. The type species was designated by monotype ( $H$. primitiva). Later, three more species were described: $H$. coeca, $H$. inaequalis and $H$. cabala.

The Hershkovitzia species parasitize bats of the genus Thyroptera Spix, 1823 (Thyropteridae). Currently, the valid species are as follows: T. tricolor Spix, 1823; T. lavali Pine, 1993; T. discifera Lichtenstein \& Peters, 1855; T. devivoi Gregorin, Gonçalves, Lim \& Engstrom, 2006 and T. wynneae Velazco, Gregorin, Voss \& Simmons, 
2014. These species are endemic to Neotropical lowland forest (Solari et al. 2004), and they can be morphologically characterized by suction disk on the feet and the base of the claws on their thumbs (Bezerra et al. 2005). Individuals are usually found in palm leaves, young leaves of Heliconia L. and Calathea G. Mey (Vonhof \& Fenton 2004), dead leaves of Cecropia Loefl., and in caves used as daytime shelters. (Esbérard et al. 2007).

In this work, a new species of the genus Hershkovitzia is described from the northeast coast of Brazil. Along with the species description, we also provide illustrations and an identification key.

The ZooBank Life Science Identifier (LSID) of this publication is: urn:lsid:zoobank. org:pub:A59F64FC-34D2-4997-8D83-C234FF640E8E

\section{MATERIALS AND METHODS}

Adult flies were collected in Tabocas, Barreirinhas municipality, Maranhão (2 o58'38.57"S/43010'09.92"W and 2059'56.92"S/4307'55.22"). The host bat specimens were captured in mist nets and the flies removed with tweezers. The bat flies were preserved in 70\% ethanol. Morphological terminology follows Guimarães \& D'Andretta (1956) and Graciolli (2010). The plate numbers were used in Arabic and the divisions of the legs in Roman, as proposed by Theodor (1967).

The proposed drawings serve as a likeness only for the purpose of species identification. The regions chosen for the drawings are important for species diagnosis: abdomen of female and male (ventral and dorsal), head (dorsal and lateral) and tibia II. The drawings were done freehand in graphite on graph paper with the assistance of a stereomicroscope. The finalization of the drawings was in made on vegetal paper and nanquim and later scanned with an HP Deskjet 2600. Subsequently, the drawings were vectored and edited, using corel DRAW 2018. Drawings were saved in 1200 dpi quality.

\section{RESULTS}

\section{Hershkovitzia mariae Hrycyna, dos Santos, Rebêlo \& Graciolli sp. nov.}

Hershkovitzia sp.: Santos et al. 2013:209 (citation). Barbier and Bernard 2017: 4 (citation), 5 (citation and distribution), 7 (citation and ecorregion), 9 (citation). Barbier et al. 2017: 397 (citation).

Zoobank Life Science Identifier (LSID) - urn:lsid:zoobank. org:act:9769A50F-6862-4EDF-8BD9-E111F42535F5

Type-series. Holotype $q$ - Hershkovitzia mariae sp. nov. (Gabriela Hrycyna det. III.2018) / Brazil, MA, Barreirinhas, Tabocas, 2058'38.57"S/43010'09.92"W, 31 January 2014, host Thyroptera devivoi [ZUFMS]. Paratype $\widehat{\jmath}$ Hershkovitzia mariae sp. nov. (Gabriela Hrycyna det. III.2018)/Brazil, MA, Barreirinhas, Tabocas, 2059'56.92"S/4307'55.22"W, 21 June 2015, host Thyroptera devivoi [ZUFMS].

Type locality: Tabocas, Barrerinhas, state of Maranhão, Brazil.

Type-host: Thyroptera devivoi Gregorin, Gonçalves, Lim \& Engstrom, 2006.

Depository: Holotype and paratype: Coleção Zoológica de Referência da Universidade Federal do Mato Grosso do Sul, Campo Grande, Brazil.

Etymology: Specific epithet after Dr. Maria Aparecida Vulcano D'Andretta, for her contribution to the genus.

Diagnosis: Each eye with three setae, one seta located in the region between the eye and the others located before the eye. Gena with two setae; post-gena with two short setae. Three setae located anterior to meso-notopleural sutures. Female syntergites $1+2$ and tergites 3 and 
7 made up a whole plate; tergite 5 and 6 divided into two plates each. Sternite $1+2$ consisting of a whole plate; sternites 3, 4, 5 and 6 divided into two plates each. Sternite 7 subtriangular with lateral and median portions with depressions, strongly pigmented and without setae. Male presents all tergites and sternites formed by a whole plate.

Descripton: Head. Dorsal view - eyes with one facet; one seta medial to and near hind margin of each eye, and two setae directly in front of each eye, more evident in male (Fig. 1a). Gena with three setae, two short and one long in the middle. Post-gena with two setae (Fig. 1b). Ventral view - palps on the distal and proximal distend, with 10 setae along palps length, and

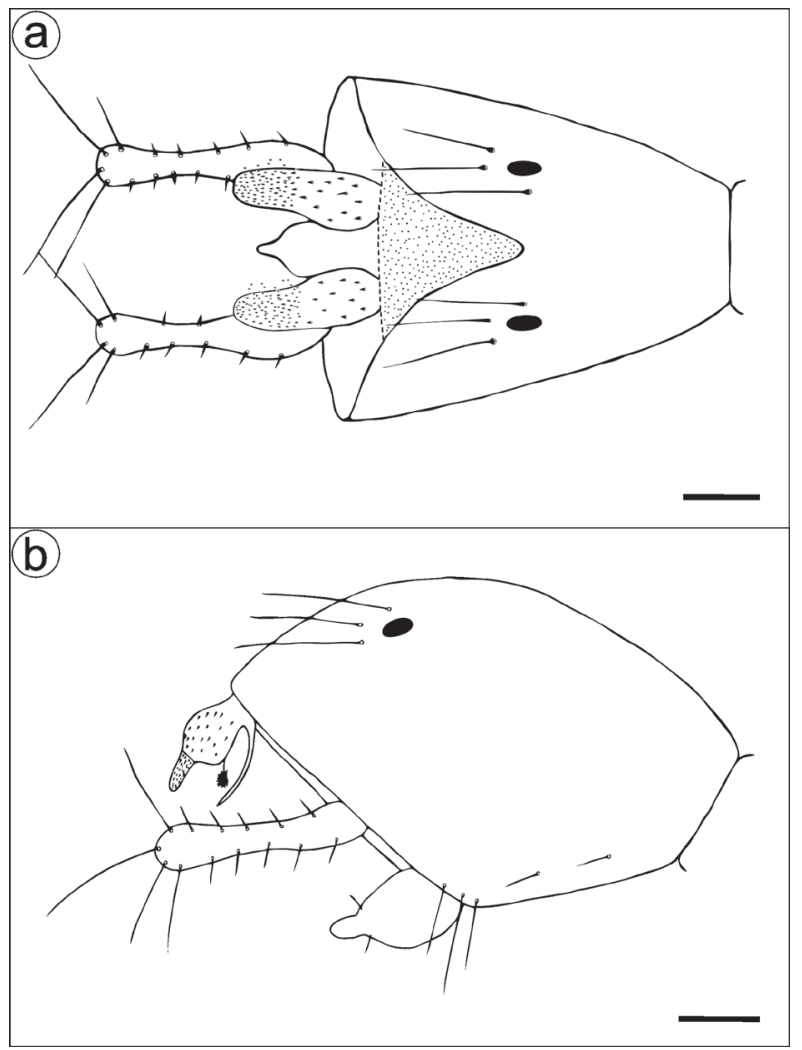

Figure 1. a) Head, female (Holotype), dorsal view, Hershkovitzia mariae sp. nov. (Scale bar $=11.7 \mathrm{~mm}$ approx.). b) Head, female (Holotype), lateral view, Hershkovitzia mariae sp. nov. (Scale bar $=11.7 \mathrm{~mm}$ approx.). four longer setae at the distal margin. Thecae wider than long.

Thorax: Dorsal view - Meso-notopleural suture with three setae. Thoracic ctenidium with 10 spines. Thoracic spiracle piriform shape. Ventral view - sternal plate with setae throughout length. Angle between oblique suture greater than 90․ Coxa I as long as wide, flattened, triangular, and without setae on anterior part. Femur I longer than wide, flattened, rectangular, ring visible and with setae throughout length. Tibia I flattened, cylindrical, and with four ventrodistal rows of setae on apical portion. Basitarsus the same size as the next three tarsi. Coxa II short, triangular and with short setae. Femur II and III longer than wide, flattened, rectangular, with setae throughout length. Visible ring, with a row of setae on anterior margin. Tibia II longer than wide, cylindrical, with setae throughout length and distal posterior margin with three rows of setae on apical portion (Fig. 2). Coxa III as wide as long, triangular, with setae throughout length. Tibia III cylindrical, with five rows of setae on apical portion.

Female. Abdomen: Tergites and sternites with numerous setae throughout length. All plates with distal margin and row of setae of unequal length. Dorsal view - Syntergite 1+2, tergites 3 and 4 entire. Tergite 5 and 6 with two

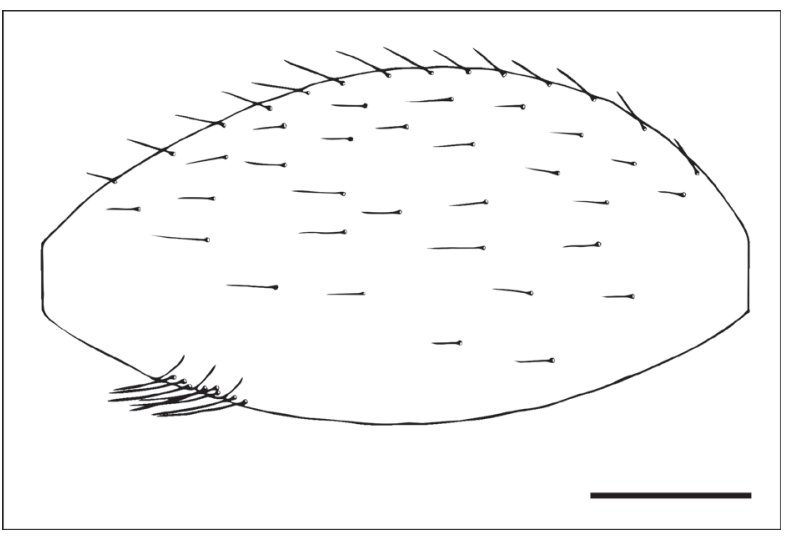

Figure 2. Tibia II, lateral view, Hershkovitzia mariae sp. nov. (Scale bar = $1 \mathrm{~mm}$ approx.). 
plates each. Tergite 7 short and with four setae along the plate. Tergite 7 with two rectangular side lobes and 4-5 setae in each lateral prominence (Fig. 3a). Ventral view - Sternite 1+2 rectangular with round margin. Ctenidium with 35 spines. Sternites 3, 4 and 5 with two plates each. Sternites 6 with two subtriangular plates. Sternite 7 subtriangular, with posterior margin almost straight and depressions on lateral and median portion of plate (Fig. 3b).

Male. Abdomen: Tergites and sternites with numerous setae throughout length. Dorsal view - All plates with distal margin with row of setae of unequal length. Syntergite $1+2$ long and triangular. Tergite 3 to 6 entire. Microtrichia on anal plate and setae only on posterior margin (Fig. 4a). Ventral view - Sternite 1+2, ctenidium

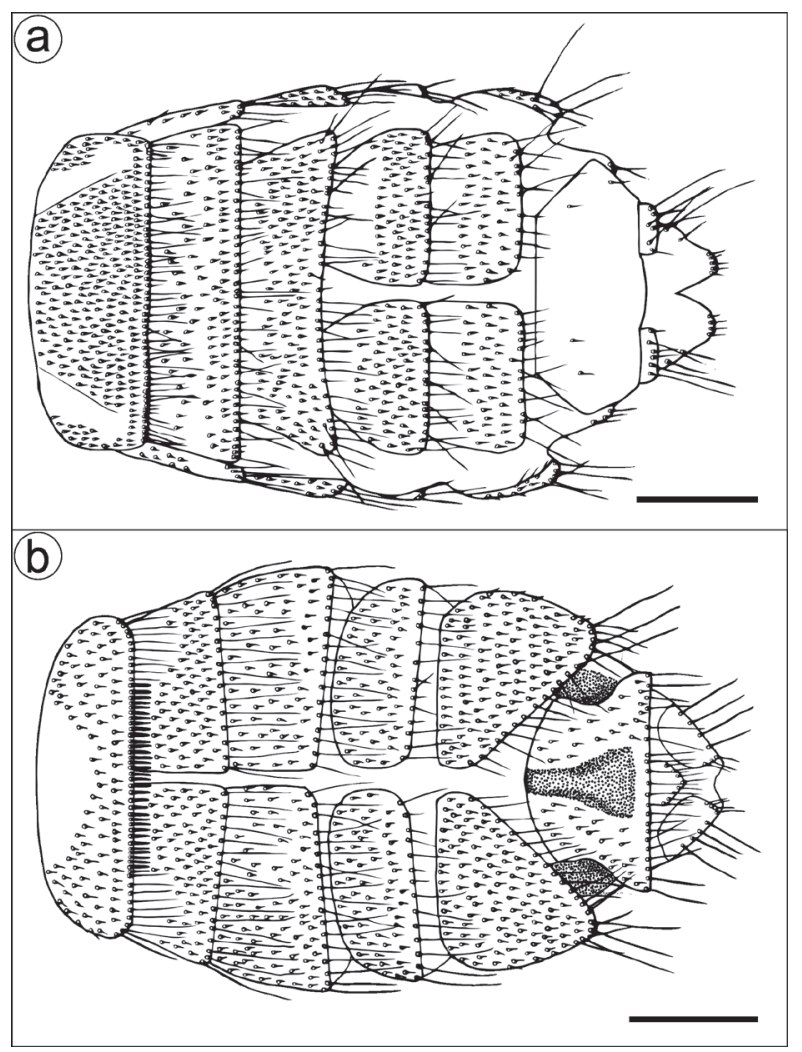

Figure 3. a) Abdomen, female (Holotype), dorsal view, Hershkovitzia mariae sp. nov. (Scale bar $=0.5 \mathrm{~mm}$ approx.). b) Abdomen, female (Holotype), ventral view, Hershkovitzia mariae sp. nov. (Scale bar $=0.5 \mathrm{~mm}$ approx.). with 50 spines, covers the entire back margin of the plate. Sternite 3 to 5 as whole plate. Sternite 5 with concavity on median posterior margin and with round lateral margins. Lateral margin with a set of setae more sclerotized than the other setae on lateral abdomen (Fig. 4b).

\section{Identification Key to species of Hershkovitzia Guimarães \& D'Andretta}

\section{Females}

1. - Row of abdominal ctenidium covers the entire posterior margin of sternite $1+2$. Tibia II with two rows in the median portion. Right angle between oblique sutures.......................2

- Row of abdominal ctenidium covers one third of the posterior margin of sternite 1+2. Tibia II with three rows in the apical portion. Obtuse angle between oblique sutures. .4

2. - Absent eyes. Sternite 7 with hexagonal shape and median region without setae. Mesonotopleural suture with two setae on each side. Gena with two setae.

\section{Hershkovitzia coeca Theodor.}

- Present eyes. Sternite 7 with rounded posterior margin. Meso-notopleural suture with more than two associated setae. 3

3. - Each eye with two associated setae, one located anteriorly and one posteriorly. Mesonotopleural suture with three associated setae. Whole tergites. Post-gena without setae. Gena with two setae.

Hershkovitzia cabala

\section{Peterson \& Lacey.}

- Each eye with two associated setae, both of which are located anterior to the eyes. Mesonotopleural suture with three associated setae. Tergite 6 divided. Post-gena with three short setae. Gena with three setae.

Hershkovitzia primitiva Guimarães \& D'Andretta.

4. - Each eye with four associated setae, all located anterior to the eyes. Meso-notopleural 


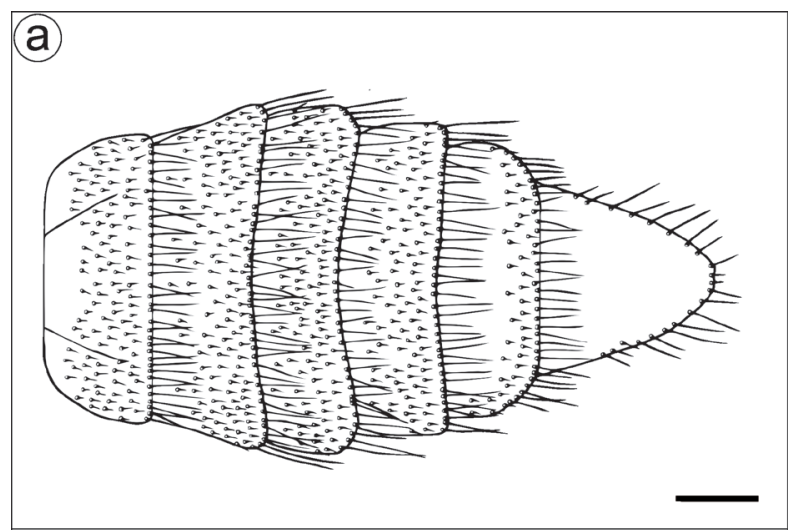

(b)

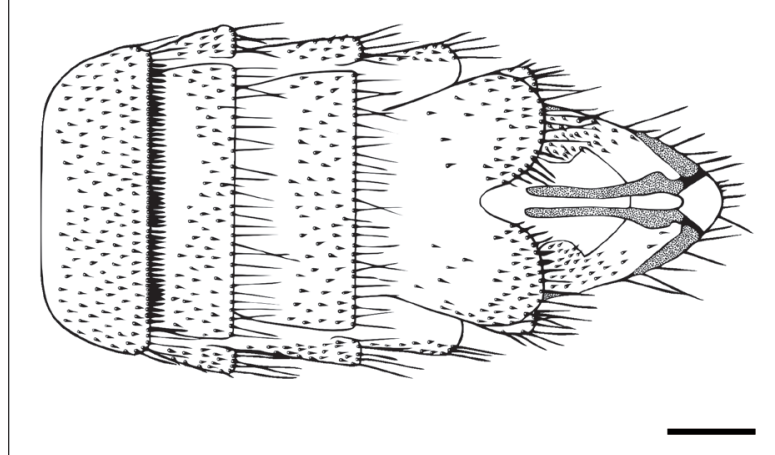

Figure 4. a) Abdomen, male (Paratype), dorsal view, Hershkovitzia mariae sp. nov. (Scale bar $=0.2 \mathrm{~mm}$ approx.). b) Abdomen, male (Paratype), ventral view, Hershkovitzia mariae sp. nov. (Scale bar $=0.2 \mathrm{~mm}$ approx.).

suture with four associated setae. Tergites 4, 5 and 6 divided. Sternites 3, 4, 5 and 6 divided. Sternite 7 subtriangular with the posterior margin almost straight and the median portion of the plate showing depressions. Post-gena with five short setae. Gena with six setae.

\section{Hershkovitzia inaequalis Theodor.}

- Each eye with three associated setae, two anterior arrows and one between the eyes. Tergites 5 and 6 divided. Sternites 3, 4, 5 and 6 divided. Meso-notopleural suture with three associated setae. Post-gena with two setae. Gena with two setae. Hershkovitzia mariae sp. nov.
Male

1. - Row of abdominal ctenidium covers all posterior margin of sternite 1+2. Mesonotopleural suture with three associated setae. .2

- Row of abdominal ctenidium covers one third of the posterior margin of sternite 1+2. Meso-notopleural suture with two or four associated setae. 3

2. - Each eye with two associated setae, all located anterior to the eye. 14 thoracic ctenidium. Post-gena with three short setae. Gena with three setae.

Hershkovitzia primitiva Guimarães \& D'Andretta.

- Each eye with three associated setae, two anterior setae and one seta between the eyes. 10 thoracic ctenidium. Post-gena with two setae. Gena with two.

Hershkovitzia mariae sp. nov.

3. - Each eye with four associated setae, all located anteriorly. Four setae in mesonotopleural suture. Ten thoracic ctenidium. Six setae in the gena. Post-gena with five short setae.

\section{Hershkovitzia inaequalis Theodor.}

4. - Each eye with two selected setae, one seta located in the anterior region and one in the posterior region. Meso-notopleural suture with three associated setae. Eleven thoracic ctenidium. Post-gena with 5 short setae. Gena with two setae.

Hershkovitzia cabala

\section{Peterson \& Lacey.}

\section{DISCUSSION}

As previously noted in the key, Hershkovitzia females can be divided into two groups. The first group is characterized by having a row of abdominal ctenidium covering the entire posterior margin of sternite $1+2$, in addition to tibia II with two rows in the median portion. 
This group is composed of $\mathrm{H}$. primitiva, $\mathrm{H}$. coeca and $H$. cabala. Hershkovitzia coeca differs from the other two species by the absence of eyes. In addition to other characters highlighted in the key, $H$. cabala differs by having all tergites composed of one plate, and $H$. primitiva differs by having tergite 6 divided into two plates.

Hershkovitzia inaequalis and Hershkovitzia mariae sp. nov compose the second group. This group is characterized by a row of ctenidium in sternite $1+2$ covering only one third of the posterior margin, apart from tibia II with three rows in the apical portion. $H$. inaequalis can be differentiated by having tergite 4 and sternites 3, 4, 5 and 6 divided into plates. On the other hand, tergite 4 of Hershkovitzia mariae sp. nov. is composed of a single plate. In $\mathrm{H}$. inaequalis, the row of ctenidium has 45 thin spines, and in Hershkovitzia mariae sp. nov., we observe 35 spines, thick and dense.

Hershkovitzia inaequalis and Hershkovitzia mariae sp. nov. have characteristics that can be seen in males and females. The head in $\mathrm{H}$. inaequalis features four setae in each eye, while Hershkovitzia mariae sp. nov. has three setae in each eye. In $\mathrm{H}$. inaequalis, the setae are located anterior to the eye, while in Hershkovitzia mariae sp. nov., two setae are located anterior to the eye, and the other seta is located between the eyes. (Fig 1a).

Hershkovitzia males are similar to Basilia males (Guimarães \& D’Andretta 1956). However, they have very subtle characteristics, making their characterization and differentiation difficult. The male of Hershkovitzia mariae sp. nov., as with the other species of the genus, has inconsistent features with respect to the abdomen. The head, thorax and legs are similar to those of the female.

Hershkovitzia mariae sp. nov. is known exclusively for parasitizing Thyroptera devivoi and represents the first record of parasitism on this species. Other species of Hershkovitzia are already known to $T$. discifera ( $H$. primitiva), $T$. tricolor (H. cabala), and T. lavali (H. inaequalis) (Guimarães \& D'Andretta 1956, Theodor 1967, Peterson \& Lacey 1985, Graciolli et al. 2007, Graciolli 2010).

Hershkovitzia mariae sp. nov. is known only to Barrerinhas, state of Maranhão. This region represents the northern limit of the Cerrado in Brazil (Santos et al. 2013). This species is the first registered to the genus Hershkovitzia for the Cerrado biome (tropical savannah), while the other species occur in the Amazon rainforest (Graciolli et al. 2007, Graciolli \& Dick 2018).

\section{Acknowledgments}

We thank the Coordenação de Aperfeiçoamento de Pessoal de Nivel Superior (CAPES) and the Conselho Nacional de Desenvolvimento Científico e Tecnológico (CNPq) (\#306216/2018-3) for supporting our research.

\section{REFERENCES}

BARBIER E \& BERNARD E. 2017. From the Atlantic Forest to the borders of Amazonia: species richness, distribution, and host association of ectoparasitic flies (Diptera: Nycteribiidae and Streblidae) in northeastern Brazil. Parasitol Res 116: 3043-3055.

BARBIER E, SOUZA AQS, BEZERRA JP, SANTOS JOF \& JÚNIOR WRT. 2017. New record, new host, and geographic distribution of Basila hughscotti Guimarães, 1946 (Diptera: Nycteribiidae). Entomol News 126: 394-399.

BEZERRA AMR, ESCARLATE-TAVARES F \& MARINHO-FILHO J. 2005. First record of Thyroptera discifera (Chiroptera: Thyropteridae) in the Cerrado of Central Brazil. Acta Chiropterol 7: 165-170.

ESBÉRARD CEL, SANTOS BS \& FARIA D. 2007. New Thyroptera tricolor Spix records in the Atlantic Forest, Brazil (Chiroptera, Thyropteridae). Braz J Biol 67: 379-380.

GRACIOLLI G. 2010. Nycteribiidae (Bat flies, Spider bat flies). In: Bronwn BV, Borkent A, Cumming JM, Wood DM, Wood NE \& Zumbado MA (Eds), Manual of Central American Diptera, Ottawa, NRC Research Press, p. 1261-1266. 
GRACIOLLI G, AUTINO AG \& CLAPS GL. 2007. Catalogue of American Nycteribiidae (Diptera, Hippoboscoidea). Rev Bras Entomol 51: 142-159.

GRACIOLLI G \& DICK CW. 2018. Checklist of World Nycteribiidae (Diptera: Hippoboscoidea) National Science Foundation.

GRACIOLLI G, DICK CW \& GUERRERO R. 2016. Family Nycteribiidae. Zootaxa 4122(1): 780-783.

GREGORIN R, GONÇALVES E, LIM BK \& ENGSTROM MD. 2006. New species of disk-winged bat Thyroptera and range extension for T. discifera. J Mammal 87: 238-246.

GUIMARÃES LR \& D'ANDRETTA MAV. 1956. Sinopse dos Nycteribiidae (Diptera) do Novo Mundo. Arq Zool 9: 127-138.

PETERSON BV \& LACEY LAA. 1985. New Species of Hershkovitzia (Diptera: Nycteribiidae) from Brazil, with a key to the described species of the genus. Proc Entomol Soc Wash 87: 578-582.

PETERSON BV \& WENZEL RL. 1987. Nycteribiidae. In: McAlpine JF, Peterson BV, Shewell GE, Teskey HJ, Vockeroth JR \& Wood DM (Eds) Manual of Nearctic Diptera. Research Branch, Agriculture Canada, Ottawa, p. 1283-1291.

SANTOS CLC, PEREIRA ACN, BASTOS VJC, GRACIOLLI G \& REBÊLO JMM. 2013. Parasitism of ectoparasitic flies on bats in the northern Brazilian cerrado. Acta Parasitol 58: 207-214.

SOLARI S, VAN DEN BUSSCHE RA, HOOFER SR \& PATTERSON BD. 2004. Geographic distribution, ecology, and phylogenetic affinities of Thyroptera lavali Pine 1993. Acta Chiropterol 6: 293-302.

THEODOR O. 1967. Genus Hershkovitzia. In: Theodor O (Ed) An illustrated catalogue of the Rothschild collection of Nycteribiidae (Diptera) in the British Museum (Natural History). Natural History Museum Publications, p. 345-352.

VELAZCO PM, GREGORIN R, VOSS RS \& SIMMONS NB. 2014. Extraordinary local diversity of disk-winged bats (Thyropteridae: Thyroptera) in northeastern Peru, with the description of a new species and comments on roosting behavior. Am Mus Novit 3795: 1-28.

VONHOF MJ \& FENTON MB. 2004. Roost availability and population size of Thyroptera tricolor, a leaf-roosting bats, in north-eastern Costa Rica. J Trop Ecol 20: 291-305.

\section{How to cite}

HRYCYNA G, DOS SANTOS CLC, REBÊLO JMM \& GRACIOLLI G. 2021. A New Species of Hershkovitzia (Diptera: Nycteribiidae) from Maranhão, Brazil. An Acad Bras Cienc 94: e20191161. DOI 10.1590/0001-3765202120191161.

Manuscript received on September 24, 2019;

accepted for publication on January 15, 2020

\section{GABRIELA HRYCYNA ${ }^{1}$}

https://orcid.org/0000-0002-1632-1023

\section{CIRO L.C. DOS SANTOS ${ }^{2}$}

https://orcid.org/0000-0002-0987-3620

\section{JOSÉ M.M. REBÊLO}

https://orcid.org/0000-0002-0223-0980

\section{GUSTAVO GRACIOLLI ${ }^{4}$}

https://orcid.org/0000-0002-1144-3486

${ }^{1}$ Programa de Pós-Graduação em Biologia Animal, Universidade Federal do Mato Grosso do Sul, Instituto de Biociências, Av. Costa e Silva, s/n, Campo Grande, 79070-900 Mato Grosso do Sul, MS, Brazil

${ }^{2}$ Universidade Federal do Maranhão, Centro de Ciências Socias, Saúde e Tecnologia, Av. da Universidade, s/n, 65915-240 Imperatriz, MA, Brazil

${ }^{3}$ Universidade Federal do Maranhão, Departamento de Biologia, Centro de Ciências Biológicas e da Saúde, Av. dos Portugueses, 1966, 65080-805 São Luís, MA, Brazil

${ }^{4}$ Universidade Federal do Mato Grosso do Sul, Instituto de Biociências, Av. Costa e Silva, s/n, Campo Grande, 79070-900 Mato Grosso do Sul, MS, Brazil

Correspondence to: Gabriela Hrycyna

E-mail:gabrielahrycyna@gmail.com

\section{Author contributions}

Gabriela Hrycyna and Gustavo Graciolli: manuscription preparation. Ciro L.C. dos Santos and José M.M. Rebêlo: data collection and manuscript revision.

\section{(cc) BY}

